\title{
Uetisk av nevrologene ikke å tilby pasienter med multippel sklerose cytostatikabehandling med autolog stamcellestøtte
}

\author{
Siden 1995 er over 1000 pasienter med multippel sklerose blitt behandlet med cytostatika med autolog \\ stamcellestøtte internasjonalt. Resultatene er nå klart bedre enn for bremsemedisinbehandling og tyder \\ på at behandlingen kan stoppe sykdommen.
}

Multippel sklerose er en autoimmun sykdom i sentralnervesystemet hvor autoreaktive lymfocytter skader oligodendrocytter (myelinskjeder) og aksoner. Cytostatikabehandling med autolog stamcellestøtte (Hematopoietic Stem Cell Transplant, HSCT) er etablert kreftbehandling og utføres rutinemessig i universitetssykehus. Det er mindre kjent at denne behandlingen virker mot multippel sklerose og andre autoimmune sykdommer $(1,2)$.

I løpet av snart 20 år er protokollene for cytostatikabehandling med autolog stamcellestøtte ved multippel sklerose forbedret. Behandlingsresultatene er gode $(3,4)$ og mortalitet og bivirkninger på et forsvarlig nivå. Ved sentre der man har erfaring med metoden er behandlingsmortaliteten godt under $1 \%$ (og godt under $0,5 \%$ for ikkemyeloablativ cytostatikaprotokoll) $(5,6)$. Fem år etter behandling er det hos $70 \%$ ingen tegn til sykdomsaktivitet (5). Etterspørselen etter behandlingen skyldes svært lav livskvalitet hos mange pasienter med multippel sklerose samt metodens behandlingsvindu: Effekten er størst tidlig i sykdomsforløpet og mindre eller fraværende senere.

Den mest effektive behandlingen for multippel sklerose anvendes knapt Hos mange pasienter med multippel sklerose er livskvaliteten så lav at HSCTbehandling fremstår som det beste alternativet - en engangsbehandling med mellomdose/lavdose (myeloablativ/ikke-myeloablativ) cytostatika som utraderer autoreaktive lymfocytter. Dette gir en god sjanse til å slippe kroniske plager på grunn av sykdomsaktivitet, fallende funksjonsnivå, medikamentbivirkninger og overgang til sekundær progredierende multippel sklerose (kronisk nevrodegenerasjon) (3).

Bremsemedisinene har det samme behandlingsvinduet som HSCT-behandling, men har kun immunmodulerende/immunsuppressiv effekt på autoreaktive lymfocytter og kan verken stoppe sykdommen eller hindre overgang til sekundær progredierende multippel sklerose (3). Bivirkningene forringer livskvaliteten betydelig hos mange, og de mest virkningsfulle bremsemedisinene har alvorlige bivirkninger som tidsbegrenser bruken. Ofte vedvarer plager på grunn av fortsatt sykdomsaktivitet.
Internasjonalt betrakter imidlertid de fleste nevrologer fortsatt cytostatikabehandling med autolog stamcellestøtte som eksperimentell behandling, selv om det i over ti år har foreligget gode resultater (7). Mange land krever at slik behandling utføres innen-

\section{«Når fase 1-2-studier på alvorlige sykdom- mer viser at den nye behandlingen er mode- rat til betydelig bedre enn den etablerte, er prospektive, randomi- serte, kontrollerte studier uetisk»}

for prospektive, randomiserte, kontrollerte studier, hvor kontrollgruppen får bremsemedisiner og intervensjonsgruppen HSCTbehandling. Nevrologene forventer at det vil ta flere år før det foreligger tilstrekkelige forskningsresultater til å avgjøre om behandlingen kan tilbys utenfor slike studier.

Inklusjonskriteriene til disse studiene er svært strenge - de er basert på type multippel sklerose, alder, antall årlige attakker, kontrastladende lesjoner på MR og bruk av minst to bremsemedisiner uten tilstrekkelig effekt. Fase 2-studier fra universitetssykehus i Sverige, Italia, Israel, Russland med flere tyder på at HCST-behandling har effekt også på progredierende multippel sklerose, hos eldre pasienter, hos dem som ikke har årlige attakker og hos dem som ikke har kontrastladende lesjoner (8). Disse har i dag få eller ingen steder å henvende seg for å få HSCT-behandling.

For meg er det uforståelig at ett av inklusjonskriteriene er at man må ha brukt to bremsemedisiner. For mange innebærer dette at kriteriene for alder og sekundær progredierende multippel sklerose ikke lenger innfris, at de får tiltakende irrever- sibel nerveskade og at behandlingen kommer for sent.

\section{Hindre}

De første HSCT-studiene inkluderte hovedsakelig pasienter med langkommet primærog sekundær progredierende multippel sklerose. Hos disse var det mindre behandlingseffekt og flere komplikasjoner. Mange nevrologer tror fortsatt at behandlingsmortaliteten ligger på flere prosent og at HSCTbehandling kun er indisert hos yngre med svært hyppige attakker eller når all annen behandling har feilet (3). Anmodninger om å få denne behandlingen avvises med at den er for farlig eller at sykdommen er for stabil. Også det siste synes jeg er vanskelig å forstå, siden sykdomsforløpet hos pasienter med multippel sklerose som oftest ikke lar seg forutsi (9). Av pasienter med attakkvis sykdom utvikler $80-85 \%$ sekundær progredierende multippel sklerose i årenes løp (3). Over halvparten er helt ute av arbeidslivet 20 år etter sykdomsdebut (10).

Forskerne mangler forskningsmidler. De får lite fra det offentlige og ingenting fra legemiddelfirmaene, som fokuserer på egne bremsemedisiner. Resultatet er en altfor langsom fremdrift i kliniske studier på HSCT-behandling av multippel sklerose. Eksempelvis møttes europeiske og amerikanske forskere i 2008 for å diskutere designen av en prospektiv randomisert, kontrollert multisenterstudie. Etter et nytt møte i 2009 publiserte de i 2012 fremskrittene i utarbeidingen av en slik studie (11). Den er ennå ikke påbegynt.

Nevrologene avgjør om det foreligger indikasjon for HSCT-behandling og hematologene utfører den. Dette krever samarbeid. I Norge stiller begge faggruppene spørsmål ved om det foreligger nok ressurser til å utvide behandlingstilbudet.

\section{HSCT-behandling i Norge}

Kun tre pasienter med multippel sklerose har fått HSCT-behandling i Norge (Haukeland universitetssykehus). Nasjonalt kompetansesenter for multippel sklerose i Bergen har svært strenge inklusjonskriterier, og de har ingen kliniske studier på HSCT-behandling. I Sverige har man hatt kliniske studier siden 2004 og har behandlet over 70 pasienter, herav flere nordmenn 
som ikke fikk behandlingen i Norge. Resultatene har vært gode, og behandlingstilbudet utvides (5). Flere nordmenn som ikke oppfylte inklusjonskriteriene i Norge, har fra 2011 fått HSCT-behandling i utlandet med godt resultat - de har kommet seg tilbake i jobb og fått livskvaliteten tilbake (12). Likevel har MS-forbundets anmodninger til Nasjonalt kompetansesenter for multippel sklerose om å starte kliniske studier på HSCT-behandling og ha mindre strenge inklusjonskriterier, vært forgjeves.

\section{Etikk}

Hematologer og nevrologer som har forsket på HSCT-behandling av multippel sklerose, har i over ti år etterlyst midler til prospektive, randomiserte, kontrollerte studier. I mellomtiden er det kommet stadig flere resultater fra fase 2-studier. Når fase 1-2studier på alvorlige sykdommer viser at den nye behandlingen er moderat til betydelig bedre enn den etablerte, er prospektive, randomiserte, kontrollerte studier uetisk. I stedet har man for eksempel anvendt historiske kontrollpersoner, slik at flest mulig snarest skal få den beste behandlingen.

En etisk forutsetning for randomiserte, kontrollerte kliniske studier, er at det på forhånd ikke foreligger noen klar formening om hvem - behandlings- eller kontrollgruppen - som vil komme best ut (13-16). Jeg mener at denne forutsetningen ikke lenger innfris når det gjelder HSCT-behandling ved multippel sklerose. Historiske kontrollpersoner fra bremsemedisinstudier (forskningsdata fra mange tusen pasienter med multippel sklerose) utgjør et tilstrekkelig sammenlikningsgrunnlag $(17,18)$.

\section{Sigbjørn Rogne}

sigbjorn.rogne@unn.no
Sigbjørn Rogne (f. 1965) er spesialist i fordøyelsessykdommer og i geriatri og arbeider som rådgivende lege ved Legeavdelingen, Medisinsk klinikk, Universitetssykehuset Nord-Norge. Forfatter har fylt ut ICMJE-skjemaet og oppgir følgende interessekonflikt: Han har selv multippel sklerose.

\section{Litteratur}

1. Farge D, Labopin M, Tyndall A et al. Autologous hematopoietic stem cell transplantation for autoimmune diseases: an observational study on 12 years' experience from the European Group for Blood and Marrow Transplantation Working Party on Autoimmune Diseases. Haematologica 2010; 95: $284-92$

2. Burt RK, Marmont A, Oyama Y et al. Randomized controlled trials of autologous hematopoietic stem cell transplantation for autoimmune diseases: the evolution from myeloablative to lymphoablative transplant regimens. Arthritis Rheum 2006; 54: 3750-60.

3. Pfender N, Saccardi R, Martin R. Autologous hematopoietic stem cell transplantation as a treatment option for aggressive multiple sclerosis. Curr Treat Options Neurol 2013; 15: 270-80.

4. Atkins HL, Freedman MS. Hematopoietic stem cell therapy for multiple sclerosis: top 10 lessons learned. Neurotherapeutics 2013; 10: 68-76.

5. Burman J, lacobaeus E, Svenningsson A et al. Autologous haematopoietic stem cell transplantation for aggressive multiple sclerosis: the Swedish experience. J Neurol Neurosurg Psychiatry 2014; 85: $1116-21$.

6. Coles AJ. Alemtuzumab therapy for multiple sclerosis. Neurotherapeutics 2013; 10: 29-33.

7. Saccardi R, Kozak T, Bocelli-Tyndall C et al. Autologous stem cell transplantation for progressive multiple sclerosis: update of the European Group for Blood and Marrow Transplantation autoimmune diseases working party database. Mult Scler 2006: 12: 814-23.

8. Muraro P, Pasquini M, Atkins $\mathrm{H}$ et al. Long-term outcomes after autologous haematopoietic cell transplantation for multiple sclerosis: a joint study from the Center for International Blood and Marrow Research (CIBMTR) and the European Group for Blood and Marrow Transplantat, 39th Annual Meeting of the European-Group-for
Blood-and-Marrow-Transplantation (EBMT). London: Nature Publishing Group (NPG), 2013.

9. Schlaeger R, D'Souza M, Schindler C et al. Prediction of long-term disability in multiple sclerosis. Mult Scler 2012; 18: 31-8.

10. Bøe Lunde HM, Telstad W, Grytten N et al. Employment among patients with multiple sclerosis a population study. PLoS ONE 2014; 9: e103317.

11. Saccardi R, Freedman MS, Sormani MP et al. A prospective, randomized, controlled trial of autologous haematopoietic stem cell transplantation for aggressive multiple sclerosis: a position paper. Mult Scler 2012; 18: 825-34.

12. Førde 0. Snart stamcelletransplantasjon i Norge? MS-bladet 2014

13. World Medical Association. World Medical Association Declaration of Helsinki: ethical principles for medical research involving human subjects. JAMA 2013: 310: $2191-4$.

14. Edwards SJ, Lilford RJ, Hewison J. The ethics of randomised controlled trials from the perspectives of patients, the public, and healthcare professionals. BMJ 1998; 317: 1209-12.

15. Lilford RJ. Ethics of clinical trials from a bayesian and decision analytic perspective: whose equipoise is it anyway? BMJ 2003; 326: 980-1.

16. Kerridge I, Lowe M, Henry D. Ethics and evidence based medicine. BMJ 1998; 316: 1151-3.

17. Giovannoni G, Southam E, Waubant E. Systematic review of disease-modifying therapies to assess unmet needs in multiple sclerosis: tolerability and adherence. Mult Scler 2012: 18: 932-46.

18. Lenhoff S, Hjorth M, Holmberg E et al. Impact on survival of high-dose therapy with autologous stem cell support in patients younger than 60 years with newly diagnosed multiple myeloma: a population-based study. Blood 2000; 95: 7-11.

Mottatt 20.8. 2014, første revisjon innsendt 23.9. 2014, godkjent 30.9. 2014. Redaktør: Hanne Støre valeur.

Publisert først på nett. 